\title{
Insulitis in human type 1 diabetes: a comparison between patients and animal models
}

\author{
Peter In't Veld
}

Received: 31 January 2014 / Accepted: 24 June 2014 / Published online: 9 July 2014

(C) The Author(s) 2014. This article is published with open access at Springerlink.com

\begin{abstract}
Human type 1 diabetes (T1D) is considered to be an autoimmune disease, with CD8+ T-cell-mediated cytotoxicity being directed against the insulin-producing beta cells, leading to a gradual decrease in beta cell mass and the development of chronic hyperglycemia. The histopathologically defining lesion in recent-onset T1D patients is insulitis, a relatively subtle leucocytic infiltration present in approximately $10 \%$ of the islets of Langerhans from children with recent-onset $(<1$ year) disease. Due to the transient nature of the infiltrate, its heterogeneous distribution in the pancreas and the nature of the patient population, material for research is extremely rare and limited to a cumulative total of approximately 150 cases collected over the past century. Most studies on the etiopathogenesis of T1D have therefore focused on the nonobese diabetic (NOD) mouse model, which shares many genetic and immunological disease characteristics with human T1D, although its islet histopathology is remarkably different. In view of these differences and in view of the limited success of clinical immune interventions based on observations in the NOD mouse, there is a renewed focus on studying the pathogenetic process in patient material.
\end{abstract}

Keywords Autoimmunity · Insulin · Insulitis · Islets of Langerhans $\cdot$ Pancreas $\cdot$ Type 1 diabetes

\section{Human type 1 diabetes}

Type 1 diabetes (T1D) is a chronic (auto)immune disease that causes a specific destruction of most insulin-producing

This article is a contribution to the special issue on Mechanisms of Tissue Injury in Autoimmune Diseases - Guest Editor: Dan Eilat

\section{P. In’t Veld $(\square)$}

Department of Pathology, Diabetes Research Center,

Vrije Universiteit Brussel (VUB),

Laarbeeklaan 103, 1090 Brussels, Belgium

e-mail: intveld@vub.ac.be pancreatic beta cells, leading to overt hyperglycemia, a need for lifelong exogenous insulin replacement therapy and a high risk for developing debilitating chronic complications. Although the disease can occur at any age, there is a peak in newly diagnosed cases between 5 and 7 years of age and at or near puberty. In contrast to other autoimmune diseases, where there is a clear female preponderance, slightly more males develop T1D than females. The incidence shows geographical variability, ranging between 0.1 and 60 cases per 100,000 people, but its true level is difficult to ascertain as the disease is probably under-diagnosed, with many T2D patients also showing signs of immunological involvement [1].

The classical model for the pathogenesis of T1D is that an environmental factor triggers autoimmunity in genetically susceptible individuals. As discussed below autoantibodies against insulin develop first, followed by other types of autoantibodies, often directed against components of the insulin secretory granule. The presence of autoantibodies is usually taken as a sign of ongoing beta cell destruction, with beta cell mass decreasing as autoimmunity expands as witnessed by the increasing number of autoantibodies. The decrease first becomes evident as signs of glucose intolerance develop, followed by clinical diabetes when a threshold of residual beta cell mass is reached that is usually suggested to be around $10 \%$ of normal [2]. As will be shown, many elements of this classical model are currently under debate.

This review deals specifically with insulitis, a multifocal inflammatory reaction limited to the islets of Langerhans considered to be characteristic for T1D and responsible for the severe loss of insulin-producing beta cells, resulting in loss of glycemic control and its clinical consequences. It summarizes the main findings in patients and discusses the similarities and differences of the human disease with a frequently used animal model for the disease, the non-obese diabetic (NOD) mouse. The genetics, immunology and clinical aspects of the disease have been discussed in many excellent reviews $[1,3-5]$ and will only be discussed briefly. 
Progress in establishing the etiopathogenesis of T1D has been slow. There are several reasons for this: (a) the diffuse nature of the endocrine pancreas makes it a difficult object to study. The endocrine islets of Langerhans are scattered throughout the exocrine parenchyma and form only 1-2\% of gland volume [6]. The focal nature of some of the histopathological changes, with inflammatory lesions observed in some pancreatic lobes but not in others, requires multiple samples for study. In addition, some of the lesions, like insulitis, are transient and usually only observed in recentonset patients. (b) Pancreatic biopsies are not normally taken in T1D patients due to the risk of pancreatitis. Biopsies have only been used in small series of recent-onset T1D patients [7]. Although initially considered to be relatively safe [8], they were later shown to have considerable side-effects and recent clinical trials were ended prematurely. Very few T1D patients have therefore been biopsied. (c) Due to the nature of the pancreatic gland, with its high content of digestive enzymes, the tissue is prone to rapid autolysis and well-preserved tissue is often only obtained from patients who were autopsied within a few hours after death. (d) Improved clinical management has resulted in fewer patients dying in diabetic ketoacidosis, leading to a decreased number of cases coming to autopsy. Together, these factors make that very few cases are available for study. The most characteristic lesion in T1D, the presence of an inflammatory infiltration of the islets of Langerhans (insulitis), has been reported in cumulative total of only 150 cases collected over the past 100 years [9]. Most of these cases are no longer available for study; detailed clinical information is often lacking and the material is usually fixed and paraffin-embedded, which limits molecular analysis. In practice, this means that few pathologists have ever seen insulitis during their professional career and that each year on average only one or two new recent-onset T1D cases become available for study worldwide.

The lack of human material has led many investigators to focus on animal models for the disease. In this context, the NOD mouse has become the model of choice. The NOD mouse shares many characteristics with human T1D, but as will be discussed below, there are also considerable differences. Although animal models yield invaluable information on molecular and cellular processes under conditions of autoimmunity, they also carry the risk that they may not represent the human disease in all its complexity, risking a situation where our view of disease progression is to a large extent derived from animal studies rather than from observations in patients. Careful and continuous validation of the animal model is therefore necessary to mitigate such a risk. Differences between the NOD mouse model and T1D patients have been detailed in a number of recent overviews [10-12], and concern has been raised that the differences in etiopathogenesis might be more profound than previously realized. Such concerns have been amplified by the fact that many immune intervention studies, often based on often dramatically positive results in NOD mice, resulted in limited success in patients [13].

Many potential treatments have been developed in the NOD mouse by which the disease can be postponed, prevented, or even cured after onset of overt symptoms. These interventions were tabulated in a number of reviews in which it was noted that $>195$ immune interventions were successful in the NOD model, but that virtually none were effective in patients [11,12]. One immune intervention developed in the NOD mouse model, consisting of a series of low dose anti-CD3 antibody injections [14], was found to transiently preserve residual beta cell function in patients when given shortly after disease onset [15]. However, the effects are minor compared to those in the NOD mice, where the same treatment leads to complete remission.

Due to these somewhat disappointing results, there is a renewed interest in islet pathology in human material in order to validate previous observations made in the NOD mouse and to study in more detail any differences that are established. Such new research is facilitated by the recent establishment of large tissue banks with optimally preserved human donor pancreas obtained from control, sub-clinical T1D or recentonset T1D subjects $[9,16]$.

\section{The discovery of insulitis}

Insulitis is defined as a predominantly lymphocytic infiltration, limited to the islets of Langerhans. It was first described in 1902 in a 10-year-old who died in ketoacidosis [17] and was termed 'insulitis' by the Swiss pathologist von Meyenburg [18]. Although initially considered to be a rare event, it was later found to be characteristic for diabetes in children with recent-onset $(<1$ year) disease $[19,20]$. The infiltrate contains predominantly CD8+ lymphocytes, in addition to CD4+ lymphocytes, B lymphocytes and macrophages [21]. Cellular immunity is accompanied by humoral immunity, with circulating autoantibodies against several different beta cell autoantigens [1]. The nature of the autoantigen against which the immune response is directed is still being debated, as will be discussed below.

Although insulitis was first observed more than a century ago [17], its true significance was not recognized until 1958 when Lecompte [20] observed that the lesion appeared to be characteristic for children with acute onset disease and short duration. He stressed that the lesion was relatively rare, but that it might be under-diagnosed as it is easily missed using the conventional stains then in use. In 1965, Gepts [19] was able to assess the incidence of insulitis in a large cohort of patients: he studied 22 recent-onset cases $(<1$ year) of diabetes below the age of 40 and found that 15 cases $(68 \%)$ showed insulitis. He also observed that the insulitic lesions appeared to be transient as they were no longer present in patients with a 
disease duration of $>1$ year. Lastly, he showed that beta cell mass in his study group was reduced to approximately $10 \%$ of normal controls and that many islets were atrophic, consisting only of non-beta cells. Arguably, he laid the basis for the classification of T1D as an autoimmune disease [22]. In a 1978 follow-up study [23], using the then newly developed immunohistochemical staining techniques for islet hormones, he observed that insulitis preferentially targeted islets with remaining beta cells and that it was virtually absent in islets from which the beta cells had disappeared. This led him to propose that 'insulitis represents an immune reaction of the delayed type, specifically directed against beta cells'.

His studies were confirmed by Foulis [24], who used a computerized survey of deaths in the UK and was able to retrieve tissue blocks of 119 patients who died in diabetic ketoacidosis before the age of 20 . He observed insulitis in 47 out of 60 patients with recent-onset $(<1$ year) disease (78 \%). He observed that insulitis was present in $23 \%$ of the insulin-containing islets, and in $1 \%$ of the insulin-deficient islets, thus confirming Gepts's observation that the immunological reactivity appeared to be directed specifically to beta cells.

Together, the studies by Gepts and Foulis represent almost half of the 150 cases with insulitis that have been described up to this day [7, 8, 17-20, 23-54]. Major follow-up studies have been lacking due to the reasons outlined above, and only recently a renewed effort to study insulitis in human T1D was initiated using large biobanks of human donor pancreas in Brussels and Gainesville-FL (JDRF-nPOD).

\section{Phenotyping insulitis}

The infiltrating cells in insulitic lesions were first phenotyped in a 12-year-old girl who died 1 month after diagnosis [26]. Immunohistochemical staining showed that these cells consisted mainly of T lymphocytes, with the T-cytotoxic/ suppressor subtype being most abundant, and T-helper cells and other leucocytes being present at lower frequency. Later studies confirmed a predominantly CD8+ T-cell phenotype but also pointed to an important presence of macrophages [35, 42]. An extensive reanalysis of 279 individual islets with insulitis from 29 recent-onset cases showed that the composition differed depending on the stage of insulitic lesion: early stage lesions, where beta cell loss is not yet evident, showed infiltration of predominantly $\mathrm{CD} 8+\mathrm{T}$ cells in addition to CD68+ macrophages, CD4+ T lymphocytes and CD20+ B lymphocytes. late-stage insulitic lesions, with $<10 \%$ beta cells in the islets, showed a similar composition, with the exception of CD20+ B lymphocytes that were four-fold more frequent than in early stage lesions. Tetramer staining of HLA-0201positive patients [29] with a disease duration of $<1$ week to 8 years showed that CD8+ T cells found within insulitic lesions recognize several different islet antigens including amino acid sequences from insulin, preproinsulin (aa 1523), islet-specific glucose-6-phosphatase catalytic subunit related protein (IGRP, aa 265-273), IA-2 (tyrosine phosphataselike protein aa 797-805), GAD65 (glutamic acid decarboxylase aa 114-123) and preproIAPP (human islet amyloid polypeptide precursor protein aa 5-13). The four recent-onset patients that were tested showed only islets with a single positivity for islet-autoreactive $\mathrm{T}$ cells (insulin or IGRP), indicating a possible clonal origin of the infiltrating $\mathrm{T}$ cells, while four chronic patients with disease duration longer than a year showed multiple islet-reactive specificities. These results are consistent with an autoimmune CD8 T-cell-mediated beta cell loss that is initially directed against insulin (and or IGRP) epitopes and later, because of the release of additional beta cell antigens caused by ongoing beta cell death, evolves into a broader reactivity pattern. The (tentative) identification of Tcell specificities opens new strategies for treatment, possibly via the induction of tolerance. Clearly, studies into the specificity of the infiltrating CD8 T cells are still in an early phase. The number of patients that were investigated was small, they were already diagnosed with the disease, and as the authors stress themselves, the signal intensity of the tetramer staining was very low. Interestingly, the CD8 specificity pattern closely resembles the pattern of autoantibodies found in T1D patients and in individuals at risk for developing the disease. The autoantibodies that are routinely tested using internationally validated assays include reactivities against insulin (IAA - insulin autoantibodies), IA-2 autoantibodies (IA2A; ICA512), GAD autoantibodies (GADA) and zinc transporter8 autoantibodies (ZnT8A) [1, 2]. Whether the similarity in reactivity pattern with that found in $\mathrm{CD} 8+$ islet $\mathrm{T}$ cells indicates related pathogenetic pathways or is an indication that both phenomena are a consequence rather than a cause of beta cell death, with the secretory-granules having a strong immunogenic effect due to their particulate nature, is open to discussion. Immunophenotyping studies in preclinical lesions [37] will be of particular importance in this context.

Insulitis in the preclinical phase

The lesions we observe in recent-onset T1D are probably the result of a process that in many cases has been active for a considerable period of time. Diabetes registry studies, especially in first-degree relatives of T1D patients, have shown that autoantibodies against islet cell antigens can be present many years before clinical disease. They confer a risk that depends on the number of autoantibody specificities being present [55]. Autoantibodies tend to appear sequentially, with IAA appearing first, followed by GADA, IA-2A and ZnT8A [56]. They can occur over a wide age range and positivity can be transient, although only persistent positivity appears to be associated with a high risk of progression to T1D. Development of IA-2A and/or ZnT8A confer a high and 
age-independent risk of approximately $50 \%$ of developing the disease within a 5-year period.

Studies on autoantibody-positive non-diabetic organ donors surprisingly showed only limited evidence of islet lesions and beta cell damage [29, 37, 57-59]. The cumulative data from these studies show that only two out of the 72 autoantibody-positive subjects showed diabetes-related histopathological changes [37]. In both subjects, $<10 \%$ of the islets were affected with insulitis; occasional pseudoatrophic islets devoid of beta cells were seen and relative beta cell area was in the normal to high normal range. Both cases presented with multiple autoantibodies in combination with a susceptible HLA-DQ genotype. Interestingly, one subject showed a considerable level of beta cell replication that was limited to the Tcell-infiltrated islets. Together, these results raise questions about our current view of the natural history of the disease and the time course of beta cell loss. They do not support a model where autoantibody positivity is a surrogate marker for extensive beta cell damage and a decreasing beta cell mass.

Insulitis is frequent in young patients

As outlined above, insulitis is only found in a relatively small subset of diabetic patients. When the histopathological data from all population-based studies are combined [7, 19, 23, $27,29,32,38,56,60,61]$, a total of 247 cases can be analysed and stratified according to age at onset and duration of disease. Insulitis was present in $19 \%$ of all cases. It was most prominent in young patients ( $0-14$ years) in the first year after diagnosis: 32 of the 47 patients $(68 \%)$ in this age group showed clear insulitic lesions, albeit in often a small subset of islets. In contrast, the lesion was rare in young patients with chronic disease ( $>1$ year), where it was only found in $4 \%$ of cases (Table 1). The study by Foulis [24] was not included in this meta-analysis as the paper does not give clinical data on the insulitis-negative patients. However, the overall outcome of this study, with 39/45 of young patients with a disease duration

Table 1 Fraction of T1D patients with insulitis stratified according to age at onset and duration of disease

\begin{tabular}{llll}
\hline & \multicolumn{2}{l}{ Duration of disease } \\
\cline { 2 - 4 } Age at onset (years) & $\leq 1$ year & $>1$ year & Total \\
\hline $0-14$ & $32 / 47(68)$ & $4 / 103(4)$ & $36 / 150(24)$ \\
$15-39$ & $10 / 35^{* *}(29)$ & $2 / 62$ ns $(3)$ & $12 / 97^{*}(12)$ \\
Total & $42 / 82(51)$ & $6 / 165(4)$ & $48 / 247(19)$
\end{tabular}

Data are expressed as number of patients with insulitis versus total number in group (percentage). Combined patient data from populationbased studies [7, 19, 23, 27, 29, 32, 38, 56, 60, 61].

$n s$ non-significant

${ }^{*} p<0.01 ;{ }^{*} p<0.05$, significance of differences versus the age group 0 14 years was calculated using a chi-square test of $<1$ year ( $87 \%$ ) having insulitis, is in line with the current analysis. Interestingly, insulitis was less frequently found in older individuals (15-39 years), where only $29 \%$ of patients displayed insulitic lesions in the first year after diagnosis. The relatively low frequency in (young) adults is of interest, as it might indicate a different or less fulminant version of the disease with a slower progression of beta cell loss [9, 62].

The 2013 consensus guideline for the diagnosis of insulitis

Early pathologists described insulitis as an islet-specific infiltration of a predominantly lymphocytic nature. They stressed that the infiltrates were easy to miss in conventional stains and that the lesion was probably underdiagnosed [20]. The advent of immunohistochemistry allowed phenotyping of the infiltrating cells and facilitated their quantification. However, no consensus existed in the pathology community as to which leucocyte marker should be used or how to distinguish insulitis from background infiltration. Different thresholds of $2,3,4,5,6$ or 15 CD3- or CD45-positive islet cells were used by different authors to identify insulitis [7, 16, 21, 27, 29, 33, 37]. Recently, a JDRF-nPOD working group [63] defined the consensus criteria for the diagnosis of classical insulitis: 'Patients with insulitis are defined by the presence of a predominantly lymphocytic infiltration specifically targeting the islets of Langerhans. The infiltrating cells may be found in the islet periphery (peri-insulitis), often showing a characteristic tight focal aggregation at one pole of the islet that is in direct contact with the peripheral islet cells. The infiltrate may also be diffuse and present throughout the islet parenchyma (intrainsulitis). The lesion mainly affects islets containing insulinpositive cells and is always accompanied by the presence of (pseudo)atrophic islets devoid of beta cells. The fraction of infiltrated islets is generally low ( $<10 \%$ of islet profiles). The lesion should be established in a minimum of three islets, with a threshold level of $\geq 15 \mathrm{CD} 45+$ cells/islet before the diagnosis can be made'.

Normal islets are frequent after clinical onset

The pancreas of most recent-onset T1D patients still contains a sizeable number of insulin-positive islets: in young patients (0-14 years), approximately $38 \%$ of islets are insulin-positive up to 1 year after diagnosis. In young adults (15-39 years), this fraction is higher with $56 \%$ of islets being insulin positive (Table 2). These relatively high levels of residual beta cells contrast with the situation $>1$ year after diagnosis, where the fraction of insulin-positive islets is down to $13 \%$. Although these data refer to insulin-positivity at the islet level, and not to absolute beta cell mass, they do support the notion that an important residual number of beta cells are present in the first year after diagnosis. This residual beta cell mass appears to be most pronounced in individuals that develop the disease above 
Table 2 Percent islets with residual beta cells in T1D stratified according to age at onset and duration of disease

\begin{tabular}{llll}
\hline & \multicolumn{2}{l}{ Duration of disease } \\
\cline { 2 - 4 } Age at onset (years) & $\leq 1$ year & $>1$ year & Total \\
\hline $0-14$ & $37.9 \pm 4.1(43)$ & $13.5 \pm 6.5^{*}(13)$ & $32.3 \pm 3.7(56)$ \\
$15-39$ & $56.4 \pm 7.5(11)$ & $13.6(1)$ & $52.9 \pm 7.7(12)$ \\
Total & $41.7 \pm 3.7(54)$ & $13.5 \pm 5.5^{*}(14)$ & $35.9 \pm 3.4(68)$ \\
\hline
\end{tabular}

Data are expressed as the percent of islets that contain insulin positivity $( \pm \mathrm{SEM})$ as measured in $(n)$ patients. Combined patient data from Refs. $[24,32]$

${ }^{*} p<0.01$, significance of differences versus the group with $\leq 1$ year duration was calculated using a non-parametric Mann Whitney test

age 14 and supports the view that the disease is less fulminant in older individuals. The quantitative analysis is supported by histopathological observations in recent-onset cases, where normal insulin-containing islets, free from insulitic infiltration, were reported to be relatively frequent [19, 40, 42]. It is also in line with an analysis of recent-onset patients, where clamp-derived second phase C-peptide release was 10-40\% of that of healthy controls $[15,56]$. A recent study into the evolution of beta cell function in 948 autoantibody-positive patients $<20$ years who were followed a median period of 8 months after diagnosis showed a progressive decline of $4 \%$ per month independent of age, genetic susceptibility or BMI [64]. A similar study in a demographically more heterogeneous population showed that $93 \%$ of patients remained $\mathrm{C}$ peptide positive during the 2 years follow-up period [65]. Together, these data point to a situation where many recentonset patients have a substantial beta cell mass at diagnosis, and that this mass is decreasing relatively slowly in the months and years thereafter. The initial months after diagnosis therefore form a clear window of opportunity for studies aiming to halt or slow beta cell loss. Limiting the loss is important, as even a modest residual beta cell function will strongly benefit the patient from a clinical point of view.

Why many islets in recent-onset patients escape immune destruction while others become pseudoatrophic is not clear. One aspect that warrants careful analysis is the observation in several patients that the disease appears to be (multi) focal, with insulitis and pseudoatrophic islets only found in some 'lobules' of the gland, but not in others. It can be speculated that this is due to the anatomical structure of the gland with its multiple lobes, differences in ontogeny between ventrally derived and dorsally derived parts of the gland, structure of the ductal tree, innervation and vasculature [6].

\section{Beta cells persist in patients with chronic T1D}

Patients with chronic ( $>1$ year) T1D show a variable number of residual beta cells. Immunohistochemistry shows that on average $13 \%$ of islets still contain insulin (Table 2). The remaining islets are pseudoatrophic and consist mainly of alpha cells (A cells), in addition to somatostatin-containg cells (D cells). In islets in the ventrally derived pancreatic lobe, the pseudoatrophic islets are mainly composed of pancreatic polypeptide positive cells (PP cells) in addition to D cells.

The diffuse nature of the endocrine pancreas, the heterogeneous ontogenic origin of pancreatic lobes and differences in islet composition and the focal distribution of insulitis require that extensive sampling is carried out to evaluate residual beta cell mass in patients. Very few studies have systematically sampled the whole pancreas in order to arrive at a morphometric assessment of absolute beta cell mass: one study on four T1D patients with a disease duration of 1-34 years showed a virtual disappearance of beta cells, with mean beta cell mass going from 800 to $900 \mathrm{mg}$ in controls to virtually undetectable levels $(<20 \mathrm{mg}$ ) in chronic T1D patients, but with no changes in the absolute A, D and PP cell mass [66]. A second study on two T1D patients with a disease duration of 3 and 20 years, respectively, showed a virtual absence of beta cells in the first case and a reduction to a level of $25 \%$ of the lowest normal control in the second patient [67]. A more qualitative study of 26 T1D patients with disease duration between 2 and 54 years showed residual beta cells in $50 \%$ of the cases. Interestingly, these cells were often found to be focally distributed and present in only a limited number of lobules. No significant relation was found between the age of onset of T1D and the presence of residual insulin positivity [68].

Several subsequent studies have confirmed the presence of residual beta cells in chronic T1D patients, even up to 84 years after diagnosis [69]. The percentage of cases with residual beta cells was estimated to be between 50 and $100 \%$ [29, $68-70]$. When only childhood ( $\leq 18$ years) onset cases were included, residual beta cells were found in 6/20 chronic T1D cases [33]. The patients with residual beta cells presented with two different types of beta cell localization: in pattern A, patients showed a mixture of both insulin-deficient and insulin-containing islets, with the latter showing a clustered distribution in specific lobules of the gland. In pattern B, all islets were still insulin-containing and no insulin-deficient islets were present. A similar lobular distribution of insulincontaining islets was also observed in recent-onset patients, where insulin-containing hyperplastic islets showing insulitis were found in a limited number of pancreatic lobules, while the remainder of the gland contained only insulin-negative islets without leucocytic infiltration [19].

Patients with chronic T1D show evidence of sustained beta cell apoptosis $[65,66]$, possibly suggesting that in patients with chronic T1D there is a continuous formation of new beta cells and that these cells subsequently go into apoptosis due to recurrent autoimmunity or other causes. The statement in one of the early papers [68] on residual beta cells in chronic T1D 
patients that 'most patients whose pancreata still contain insulin cells after a diabetes duration of 10 to 20 years, will retain these insulin cells for the rest of their lives' should therefore perhaps be modified to allow for the possibility that the residual beta cells are in fact newly formed cells that have escaped apoptosis.

\section{Insulitis in the NOD mouse}

The NOD mouse model was developed more than 30 years ago by Makino and Tochino while searching for a cataractprone sub-line [71]. The strain is characterized by a high incidence of diabetes in females (approximately $80 \%$ diabetic at week 25) and a more slowly developing phenotype in males with a lower overall incidence of diabetes [72]. Diabetogenesis is caused by multiple immunodeficiencies under polygenic control with strong environmental influences that (negatively) affect disease penetration. In addition to diabetes, the NOD mouse is prone to develop other autoimmune diseases including sialadenitis and thyroiditis. Older animals develop neoplasms, including lymphomas [73]. Genetic studies have indicated that diabetes susceptibility in the NOD mouse is linked to more than 30 different loci on 15 chromosomes [74].

Stages of diabetes development in the NOD mouse

The pathogenesis and histopathology of the lesions in the female NOD islets of Langerhans can be arbitrarily divided into four stages (Table 3):

Stage 1: early infiltration (4-7 weeks)

In the NOD mouse, insulitis develops gradually, with discrete appearance of low numbers of intra-islet CD4 T-lymphocytes and their co-localization with CD11c + islet antigen presenting cells (APCs) in approximately $10 \%$ of islets at week 4 [75]. It has been suggested in some studies that this phase is preceded by myeloid cells infiltrating the NOD mouse islet [76], while others stress that such cells are normally present in all mouse strains, independent of disease susceptibility. At week 6 , approximately $30 \%$ of islets show low level of

Table 3 Pathogenesis of diabetes in female NOD mice

\begin{tabular}{lll}
\hline & Age (weeks) & Events \\
\hline Stage 1 & $4-7$ & Early infiltration \\
Stage 2 & $8-11$ & Development of inflammation \\
Stage 3 & $12-18$ & Development of cytotoxicity \\
Stage 4 & $>18$ & Clinical diabetes \\
\hline
\end{tabular}

CD4+ cell infiltration, with a median number of three cells per islet (range 1 to 55 cells per whole islet). Low numbers of $\mathrm{CD} 8+$ cells and B lymphocytes are present. Blood vessels inside the islet show increased ICAM-1 expression, and approximately $10 \%$ show VCAM-1 expression. IgG deposits are found on beta cells. Gene expression profiles suggest upregulation of immune response genes, including type I interferon-inducible genes [75].

Stage 2: development of inflammation (8-11 weeks)

At week 8, T-cell activation markers are present and the islet gene expression pattern is changed. The total number of leucocytes increases seven-fold from 2.7 to $18 \%$ of islet cells as determined by FACS in dissociated islets [75]. There is infiltration of $50-60 \%$ of islets with all major inflammatory cell types, including CD4, CD8 and CD11c cells and in some islets B cells. The infiltrating cells are preferentially located in the islet periphery and are sometimes focal at one pole of the islet periphery. Infiltration is not homogeneously distributed throughout the gland, but appears to be localized, with some pancreatic areas being affected and others not [77]. Islets show an increased endothelial expression of ICAM-1 and VCAM-1 [75]. Beta cells show increased expression of MHC class I [78]. Sizeable focal accumulations of CD3+ lymphocytes are being formed, most of which are in close contact to islet tissue. Part of these clusters (15\% at week 8 , increasing to $81 \%$ at week 20) resemble tertiary lymphoid organs (TLO), with separated T- and B-cell compartments, specialized vasculature including lymphatic vessels and high endothelial venules. The T-cell zone usually lies closest to the islet and is capped by a more distal B-cell zone. TLOs have been described in many chronic inflammatory diseases (but not human diabetes) and are thought to play a role in disease progression [77, 79-81]. Total beta cell volume in the NOD pancreas does not change significantly between 6 and 12 weeks of age [77], indicating that the predominantly peri-insulitis at this stage is of a nondestructive nature.

\section{Stage 3: cytotoxicity develops (12-18 weeks)}

Between weeks 12 and 18, there is a shift towards a cytotoxicity-related gene expression pattern together with an overall increase in the number of infiltrating cells [75]. At week $17,58 \%$ of islets are found to show peri-insulitis with a mixture of lymphocytes and monocyte-derived cells completely surrounding the islet and $5 \%$ of islets showing intra-insulitis, associated with the erosion of beta cells mass and with only some residual beta cells remaining. At week 18, all islets are affected by infiltrates, with CD45+ cells forming approximately $40 \%$ of the islet cells. Total beta cell mass gradually decreases, with a $42 \%$ reduction at week 13 and a 
$73 \%$ reduction at week 18 versus age-matched animals of a related control strain $[77,82]$.

Stage 4: clinical diabetes $(>18$ weeks)

Despite a prolonged inflammatory phase starting at week 8 , most female mice only become diabetic after weeks 18-20 [54]. At clinical onset, total beta cell volume is decreased to approximately $2.710^{9} \mathrm{\mu m}^{3}$, which is a $86 \%$ decrease compared to that found in 16-week-old diabetes-resistant control mice [2]. In diabetic animals, the pseudoatrophic islets are devoid of beta cells and are free of inflammatory infiltrates.

\section{Comparing insulitis in human disease with the NOD mouse model}

The histopathology of insulitis in the NOD mouse is different from that in patients

When insulitis in recent-onset human T1D is compared to the lesions found in the NOD mouse, some major differences can be observed (Table 4). The human disease is characterized by a relatively mild infiltration (Fig. 1a) that only affects a small fraction of the islets. Quantification of the infiltrates [75] shows an average of 25-30 CD8+ T cells per islet section, which is one or more orders of magnitude lower than the massive infiltration observed in the NOD mouse (Fig. 1b). In the mouse model, the infiltration starts with a peri-islet accumulation of CD3 + T cells, often encompassing the whole islet and increasingly showing the spatial organisation of a tertiary lymphoid organ. Neither islet encompassing periinsulitis nor TLOs have been described in the literature for the human disease. A fourth major difference between insulitis in T1D patients and NOD mice is the fraction of islets that is affected. In 18 week-old, female NOD mice virtually all islets are affected by a marked lymphocytic infiltration. Information

Table 4 Comparing insulitis in female NOD mice and patients

\begin{tabular}{|c|c|c|}
\hline Histopathological characteristics & Human & NOD \\
\hline Insulitis present at onset & Yes, low level & Yes, massive \\
\hline Infiltrate predominantly $\mathrm{T}$ cells & Yes & Yes \\
\hline $\begin{array}{l}\text { Infiltrate contains autoreactive } \\
\text { CD8+ T cells }\end{array}$ & Yes & Yes \\
\hline $\begin{array}{l}\text { Beta cell mass reduced at diagnosis } \\
\quad(\% \text { of normal })\end{array}$ & $20-30 \%$ & $10-20 \%$ \\
\hline $\begin{array}{l}\text { Massive encircling peri-insulitis prior } \\
\text { to and at onset. }\end{array}$ & No & Yes \\
\hline $\begin{array}{l}\text { Peri-insulitis with tertiary lymphoid } \\
\text { organs present at onset }\end{array}$ & No & Yes \\
\hline HLA class I hyperexpression & Yes & Yes \\
\hline
\end{tabular}
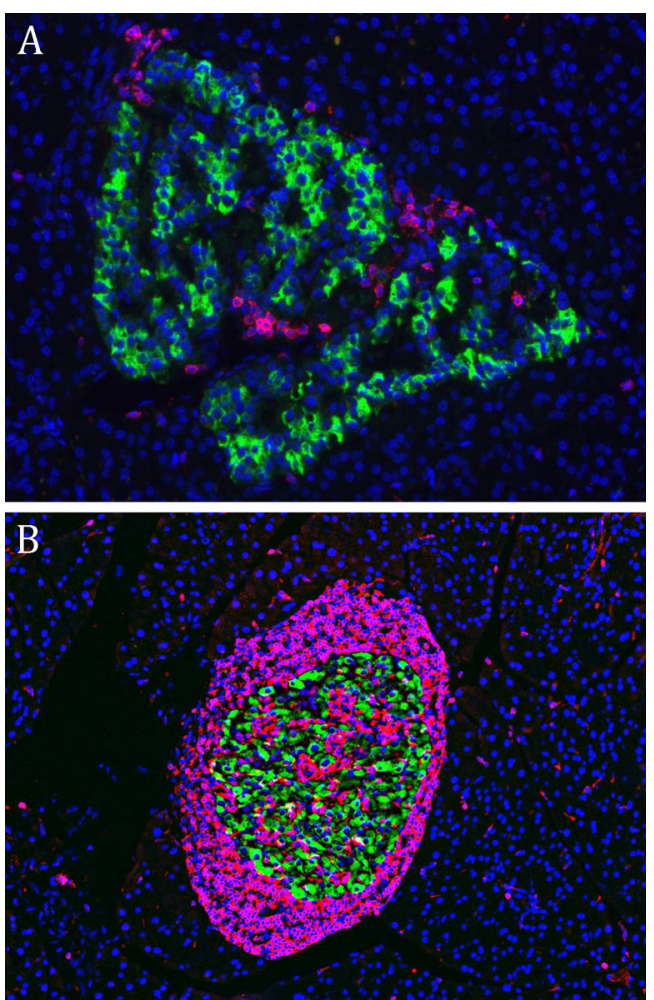

Fig. 1 a. Insulitis in a patient with T1D showing infiltrating CD45+ leucocytes $($ red $)$ in an insulin-positive islet of Langerhans ( green $)(\times 600)$. b. Insulitis in a 20 -week-old female NOD mouse showing infiltrating $\mathrm{CD} 3+\mathrm{T}$ cells in an insulin-positive islet (green) $(\times 300)$

on the histopathology of patients in a preclinical phase of the disease is limited, as only a small number of autoantibodypositive non-diabetic cases with insulitis have been described [37]. In these cases, inflammation was limited to $<10 \%$ of islets. This is similar to the situation in a group of 54 young recent-onset patients ( $<1$ year duration), where insulitis was present in an average of $9 \%$ of all islets (range $0-35 \%$ ). When only islets were analysed that still contained beta cells, an average of $32 \%$ of such islets showed insulitis [24, 32].

Immunophenotyping of insulitis shows similarities

Having stressed the morphological differences, it is also important to highlight some of the (immunological) similarities: insulitis in both species contain a high fraction of $\mathrm{T}$ cells, especially of the CD8 type, in addition to macrophages and B lymphocytes. The specificities of the autoreactive isletinfiltrating CD8 cells in both species include insulin and IGRP epitopes [74]. The infiltrates in the NOD start at 4-7 weeks, shortly before the female becomes fertile around 8 weeks of age, they become diabetic some 10-20 weeks later. In patients, diabetes incidence peaks around puberty, thus appearing to predate the disease in the NOD to a minor degree. Both show insulitis most prominently 
in the beta cell containing islets, while pseudoatrophic islets are virtually devoid of infiltrating cells. Both also show a marked overexpression of class I MHC in endocrine cells [78]. In patients, MHC class I hyperexpression was prominent in recent-onset cases [29, 32] and was also found in pseudoatrophic islets devoid of insulin positivity [29].

Early stages of insulitis are associated with beta cell replication

Observations in the NOD mouse pancreas support a model in which inflammatory infiltration stimulates replication. Beta cell replication was found to increase in pre-diabetic mice [82] and after adoptive transfer of diabetogenic spleen cells [83]. The increase in replication was found to precede a significant decline in beta cell mass and coincides with the early phase of insulitis, suggesting that inflammation associated cytokines may mediate the effect. Recent studies in NOD.RAG1 ${ }^{-/-}$mice transferred with total diabetic splenocytes reported a linear correlation between the islets manifesting insulitis and beta cell proliferation [84], although this somewhat contrasts with early observations that mitotic figures in islet beta cells are preferentially found in islets that are not yet affected by insulitis [85]. Some of the observations found in the NOD mouse may also be present in patient material: a 59-year-old autoantibody-positive organ donor without a clinical history of diabetes, but with a susceptible HLA-DQ genotype and positivity for four different autoantibodies, showed a marked Ki67-positivity in islets with ongoing insulitis [37]. The replication marker localized with both insulin and glucagon positivity, suggesting that the inflammatory environment was stimulating replication of all islet cell types. Similar findings were reported for autoantibodynegative organ donors where organs with a high level of diffuse pancreatic leucocytic infiltration were also found to present with high levels of islet cell replication [86]. Increased levels of replication were also found in ten patients with recent-onset T1D [87], but could not be confirmed in another cohort of nine recent-onset patients who died of ketoacidosis [27].

\section{Conclusion}

From a histopathological point of view, the insulitic lesions in the islet of Langerhans of recent-onset T1D patients are very different from those observed in the NOD mouse. In the animal model, the infiltrate is massive, affects all islets and has a clear peri-islet phase that precedes the development of beta cell cytotoxicity. None of these characteristics are observed in patients, where the infiltration is relatively subtle in terms of the numbers of infiltrating cells, is only observed in part of the islets and is not observed in all cases. Arguably, the disease in the NOD mouse also has many pathogenetic elements in common with the human disease: the genetic predisposition, polygenic trait and contribution of the MHC-loci, together with a strong environmental influence, are well known in both patients and NOD mice. Importantly, both appear to share a common effector mechanism, with CD8+ T-cell autoreactivity against known beta cell components. However, in view of our limited data on the human disease, care should be taken when using the observations in an autoimmune rodent model that resembles some, but not all, aspects of $\mathrm{T} 1 \mathrm{D}$, to make predictions and devise immune therapies in patients. A recent thoughtful review [88] listed the arguments pro- and contra the assertion that human T1D is a T-cell-mediated autoimmune disease. The authors argue 'that the presence of $\mathrm{T}$ cells in or around islets is not a general finding in T1D; that the process of tissue injury in T1D is not as specific as would be expected for a T-cell-mediated autoimmune disease and that the progression of T1D is generally slow and the loss of beta cells is heterogeneous throughout the pancreas, contradictory to what would be expected if the disease was mediated by a T-cell response against islet antigens', instead they offer an alternative hypothesis that an influx of different bacterial species from the duodenum via the papilla of Vater into the pancreatic ductal tree leads to the activation of ductal epithelial cells and islet cells, innate periductal inflammation, loss of exocrine parenchyma and periductal fibrosis. The periductal inflammation would be particularly harmful to the beta cells due to their low protection against NO, ROS and proinflammatory cytokines. The lobular nature of such a (repeated) innate inflammatory process could explain the heterogeneous nature of the disease in different pancreatic lobes [89]. Similarly, others have argued in favour of a viral aetiology of the disease with many different types of viruses, including rubella virus, cytomegaloviris, mumps virus and enterovirus linked to the development of T1D [90]. The most striking case being that of a 10-year-old boy who developed T1D and where coxsackie B4 virus was isolated from the pancreas and used to inoculate mice leading to insulitis and beta cell death in these animals [53].

The pioneer of islet histopathology, Philip Lecompte, proposed four explanations for his 1958 observation of insulitis in children [20], namely a direct invasion of the islets by an infectious agent, a manifestation of functional overstimulation or strain, a reaction to damage by some unknown nonbacterial agent and antigen-antibody reaction. We should conclude that these different explanations are all still relevant today and that the discussion about the aetiology of the disease is still open.

Acknowledgments The author's studies were supported by a grant of the Fonds voor Wetenschappelijk Onderzoek Vlaanderen (G019211). The expert technical assistance of Nicole Buelens is gratefully acknowledged. 
Open Access This article is distributed under the terms of the Creative Commons Attribution License which permits any use, distribution, and reproduction in any medium, provided the original author(s) and the source are credited.

\section{References}

1. Atkinson MA, Eisenbarth GS, Michels AW (2014) Type 1 diabetes. Lancet 383:69-82

2. Eisenbarth GS (1986) Type I diabetes mellitus. A chronic autoimmune disease. New Eng J Med 314:1360-1368

3. Eizirik DL, Colli ML, Ortis F (2009) The role of inflammation in insulitis and beta cell loss in type 1 diabetes. Nat Rev 5:219-226

4. Herold KC, Vignali DAA, Cooke A, Bluestone JA (2013) Type 1 diabetes: translating mechanistic observations into effective clinical outcomes. Nat Rev 13:243-256

5. Van Belle TL, Coppieters KT, von Herrath MG (2011) Type 1 diabetes: etiology, immunology, and therapeutic strategies. Physiol Rev 91:79-118

6. In't Veld P, Marichal M (2010) Microscopic anatomy of the human islet of langerhans. The islets of Langerhans. Adv Exp Med Biol 654:1-19

7. Itoh $\mathrm{N}$, Hanafusa $\mathrm{T}$, Miyazaki A, Miyagawa J, Yamagata $\mathrm{K}$, Yamamoto K, Waguri M, Imagawa A, Tamura S, Inada M, Kawata S, Tarui S, Kono N, Matsuzawa Y (1993) Mononuclear cell infiltration and its relation to the expression of major histocompatibility complex antigens and adhesion molecules in pancreas biopsy specimens from newly diagnosed insulin-dependent diabetes mellitus patients. J Clin Invest 92:2313-2322

8. Imagawa A, Hanafusa T, Tamura S, Moriwaki M, Itoh N, Yamamoto K, Iwahashi H, Yamagat K, Waguri M, Nanmo T, Uno S, Nakajima H, Namba M, Kawata S, Miyagawa J, Matsuzawa Y (2001) Pancreatic biopsy as a procedure for detecting in situ autoimmune phenomena in type 1 diabetes. Close correlation between serological markers and histological evidence of cellular autoimmunity. Diabetes 50:1269-1273

9. In't Veld P (2011) Insulitis in human type 1 diabetes: the quest for an elusive lesion. Islets $3: 1-8$

10. Leiter EH, von Herrath M (2004) Animal models have little to teach us about type 1 diabetes: 2. In opposition of this proposal. Diabetologia 47:1657-1660

11. Roep BO, Atkinson M (2004) Animal models have little to teach us about type 1 diabetes: 1 . In support of this proposal. Diabetologia 47: 1650-1656

12. Roep BO, Atkinson M, von Herrath M (2004) Satisfaction (not) guaranteed: re-evaluating the use of animal models of type 1 diabetes. Nat Rev 4:989-997

13. Staeva TP, Chatenoud L, Insel R, Atkinson MA (2013) Recent lessons learned from prevention and recent-onset type 1 diabetes immunotherapy trials. Diabetes 62:9-17

14. Chatenoud L, Thervet E, Primo J, Bach JF (1994) Anti-CD3 antibody induces long-term remission of overt autoimmunity in nonobese diabetic mice. Proc Natl Acad Sci U S A 91:123-127

15. Keymeulen B, Vandemeulebroucke E, Ziegler AG, Mathieu C, Kaufman L, Hale G, Gorus F, Goldman M, Walter M, Candon S, Schandene L, Crenier L, De Block C, Seigneurin JM, De Pauw P, Pierard D, Weets I, Rebello P, Bird P, Berrie E, Frewin M, Waldmann H, Bach JF, Pipeleers D, Chatenoud L (2005) Insulin needs after CD3-antibody therapy in new-onset type 1 diabetes. N Engl J Med 23:2598-2608

16. Campbell-Thompson M, Wasserfall C, Kaddis J, Albanese-O'Neill A, Staeva T, Nierras C, Moraski J, Rowe P, Gianani R, Eisenbarth G, Crawford J, Schatz D, Pugliese A, Atkinson M (2012) Network for pancreatic organ donors with diabetes (nPOD): developing a tissue biobank for type 1 diabetes. Diabetes Metab Res Rev 28:608-617
17. Schmidt MB (1902) Ueber die beziehung der langenhans'schen inseln des pankreas zum diabetes mellitus. Münch Med Wochenschr 49:51-54

18. Von Meyenburg M (1940) Ueber "Insulitis" bei diabetes. Schweiz Med Wochenschr 21:554-557

19. Gepts W (1965) Pathologic anatomy of the pancreas in juvenile diabetes mellitus. Diabetes 14:619-633

20. LeCompte PM (1958) "Insulitis" in early juvenile diabetes. Arch Pathol Lab Med 66:450-457

21. Willcox A, Richardson SJ, Bone AJ, Foulis AK, Morgan NG (2008) Analysis of islet inflammation in human type 1 diabetes. Clin Exp Immunol 155:173-181

22. Gale EAM (2001) The discovery of type 1 diabetes. Diabetes 50: 217-226

23. Gepts W, De Mey J (1978) Islet cell survival determined by morphology: an immunocytochemical study of the islets of Langerhans in juvenile diabetes mellitus. Diabetes 27(Suppl 1):251-261

24. Foulis AK, Liddle CN, Farquharson MA, Richmond JA, Weir RS (1986) The histopathology of the pancreas in type 1 (insulindependent) diabetes mellitus: a 25 -year review of deaths in patients under 20 years of age in the United Kingdom. Diabetologia 29: $267-274$

25. Ahmad N, Abraham AA (1982) Pancreatic isleitis with coxsackie virus B5 infection. Hum Pathol 13:661-662

26. Bottazzo GF, Dean BM, McNally JM, MacKay EH, Swift PGF, Gamble DR (1985) In situ characterization of autoimmune phenomena and expression of HLA molecules in the pancreas in diabetic insulitis. New Engl J Med 313:353-360

27. Butler AE, Galasso R, Meier JJ, Basu R, Rizza RA, Butler PC (2007) Modestly increased beta cell apoptosis but no increased beta cell replication in recent-onset type 1 diabetic patients who died of ketoacidosis. Diabetologia 50:2323-2331

28. Cecil RL (1909) A study of the pathological anatomy of the pancreas in ninety cases of diabetes mellitus. J Exp Med 11:266-289

29. Coppieters KT, Dotta F, Amirian N, Campbell PD, Kay TWH, Atkinson MA, Roep BO, von Herrath MG (2013) Demonstration of islet-autoreactive CD8 T cells in insulitic lesions from recent onset and long-term type 1 diabetes patients. J Exp Med 209:51-60

30. Crome L (1967) Fulminating diabetes with lymphocytic thyroiditis. Arch Dis Child 42:677-681

31. Dotta F, Censini S, van Halteren AGS, Marseli L, Masini M, Dionisi S, Mosca F, Boggi U, Onetti Muda A, Del Prato S, Elliott JF, Covacci A, Rappuoli R, Roep BO, Marchetti P (2007) Coxsackie B4 virus infection of beta cells and natural killer cell insulitis in recent-onset type 1 diabetic patients. Proc Natl Acad Sci U S A 104:5115-5120

32. Foulis AK, Farquharson MA, Hardman R (1987) Aberrant expression of class II major histocompatibility complex molecules by B cells and hyperexpression of class I major histocompatibility complex molecules by insulin containing islets in type 1 (insulindependent) diabetes mellitus. Diabetologia 30:333-343

33. Gianani R, Campbell-Thompson M, Sarkar SA, Wasserfall C, Pugliese A, Solis JM, Kent SC, Hering BJ, West E, Steck A, Bonner-Weir S, Atkinson MA, Coppieters K, von Herrath M, Eisenbarth GS (2010) Dimorphic histopathology of long-standing childhood-onset diabetes. Diabetologia 53:690-698

34. Gladisch R, Bayer HP, Lipinski C, Stenzel M (1975) Insulitis und perakuter diabetes mellitus. Z Kinderheilk 119:5-14

35. Hänninen A, Jalkanen S, Samli M, Toikkanen S, Nikolarakos G, Simell O (1992) Macrophages, T cell receptor usage, and endothelial cell activation in the pancreas at the onset of insulin-dependent diabetes mellitus. J Clin Invest 90:1901-1910

36. Heiberg KA (1911) Ueber diabetes bei kindern. Arch Kinderheilkunde 56:403-411

37. In't Veld P, Lievens D, De Grijse J, Ling Z, Van der Auwera B, Pipeleers-Marichal M, Gorus F, Pipeleers D (2007) Screening for 
insulitis in adult autoantibody-positive organ donors. Diabetes 56: 2400-2404

38. Junker K, Egeberg J, Kromann H, Nerup J (1977) An autopsy study of the islets of Langerhans in acute-onset juvenile diabetes mellitus. Acta Pathol Microbiol Scand Sect A 85:699-706

39. Kent SC, Chen Y, Bregoli L, Clemmings SM, Kenyon NS, Ricordi C, Hering BJ, Hafler DA (2005) Expanded T cells from pancreatic lymph nodes of type 1 diabetic subjects recognize an insulin epitope. Nature 435:224-228

40. Klöppel G, Drenck CR, Oberholzer M (1984) Morphometric evidence for a striking B-cell reduction at the clinical onset of type 1 diabetes. Virchows Arch 403:441-452

41. Lecompte PM, Legg MA (1972) Insulitis (lymphocytic infiltration of pancreatic islets) in late-onset diabetes. Diabetes 21:762-769

42. Lernmark A, Klöppel G, Stenger D, Vathanaprida C, Fält K, LandinOlsson M, Baskin DG, Palmer JP, Gown AM, Petersen JS, Li L, Edenvall H, Mauseth RS (1995) Heterogeneity of islet pathology in two infants with recent onset diabetes mellitus. Virchows Arch 425: 631-640

43. Meier JJ, Lin JC, Butler AE, Galasso R, Martinez DS, Butler PC (2006) Direct evidence of attempted beta cell regeneration in an 89 year-old patient with recent-onset type 1 diabetes. Diabetologia 49: $1838-1844$

44. Nagler W (1963) Diabetic coma with acute inflammation of islets of Langerhans. J Am Med Assoc 184:723-724

45. Nakanishi KT, Miyashita H, Okubo M, Sugimoto T, Murase T, Kosaka K, Hara M (1993) Relationship among residual beta cells, exocrine pancreas and islet cell antibodies in insulin-dependent diabetes mellitus. Metabolism 42:196-203

46. Planas R, Carillo J, Sanchez A, Ruiz de Villa MC, Nunez F, Verdaguer J, James RFL, Pujol-Borrell R, Vives-Pi M (2009) Gene expression profiles for the human pancreas and purified islets in type 1 diabetes: new findings at clinical onset and in long-standing diabetes. Clin Exp Immunol 159:23-44

47. Shimada A, Imazu Y, Morinaga S, Funae O, Kasuga A, Atsumi Y, Matsuoka K (1999) T-cell insulitis found in anti-GAD65+ diabetes with residual beta-cell function. Diabetes Care 22:615-717

48. Somoza N, Vargas F, Roura-Mir C, Vives-Pi M, Fernandez-Figuereas MT, Ariza A, Gomis R, Bragado R, Marti M, Jaraquemada D, PujolBorrell R (1994) Pancreas in recent-onset insulin-dependent diabetes mellitus: changes in HLA, adhesion molecules and autoantigens, restricted $\mathrm{T}$ cell receptor Vbeta usage, and cytokine profile. J Immunol 153:1360-1377

49. Stansfield $\mathrm{OH}$, Warren $\mathrm{S}$ (1928) Inflammation involving the islands of Langerhans in diabetes; a report on pathological findings. New Eng J Med 198:686-687

50. Uno S, Imagawa A, Okita K, Sayama K, Moriwaki M, Iwahashi H, Yamagata K, Tamura S, Matsuzawa Y, Hanafusa T, Miyagawa J, Shimomura I (2007) Macrophages and dendritic cells infiltrating islets with or without beta cells produce tumour necrosis factor alpha in patients with recent-onset type 1 diabetes. Diabetologia 50:596-601

51. Warne GL (1973) Foetal cerebral oedema with insulitis in diabetic ketoacidosis. Med J Aust 2:934-937

52. Warren S (1927) The pathology of diabetes in children. J Am Med Assoc 88:99-101

53. Yoon JW, Austin M, Onodera T, Notkins AL (1979) Virus-induced diabetes mellitus: isolation of a virus from the pancreas of a child with diabetic ketoacidosis. N Engl J Med 300:1173-1179

54. Foulis AK, Stewart JA (1984) The pancreas in recent-onset type 1 (insulin-dependent) diabetes mellitus: insulin content of islets, insulitis and associated changes in the exocrine tissue. Diabetologia 26:456-461

55. Verge CF, Gianani R, Kawasaki E, Yu L, Pietropaolo M, Jackson RA, Chase HP, Eisenbarth GS (1996) Prediction of type I diabetes in firstdegree relatives using a combination of insulin, GAD and ICA512bcd/IA-2 autoantibodies. Diabetes 45:926-933
56. Gorus FK, Keymeulen B, In’t Veld PA, Pipeleers DG (2013) Predictors of progression to type 1 diabetes: preparing for immune interventions in the preclinical disease phase. Expert Rev Clin Immunol 9:1173-1183

57. Gianani R, Putnam A, Still T, Yu L, Miao D, Gill RG, Beilke J, Supon P, Valentine A, Iveson A, Dunn S, Eisenbarth GS, Hutton J, Gottlieb P, Wiseman A (2006) Initial results of screening of non-diabetic organ donors for expression of islet autoantigens. J Clin Endocrinol Metab 91:1855-1861

58. Oikarinen M, Tauriainen S, Honkanen T, Vuori K, Karhunen P, Vasama-Nolvi C, Oikarinen S, Verbeke C, Blair GE, Rantala I, Ilonen J, Simell O, Knip M, Hyöty (2008) Analysis of pancreatic tissue in a child positive for islet cell antibodies. Diabetologia 51: 1796-1802

59. Wagner R, McNally JM, Bonifacio E, Genovese S, Foulis A, McGill M, Christie MR, Betterle C, Bosi E, Botazzo GF (1994) Lack of immunohistologic changes in the islets of nondiabetic, autoimmune, polyendocrine patients with beta-selective GAD-specific islet cell antibodies. Diabetes 43:851-56

60. Doniach I, Morgan AG (1973) Islets of Langerhans in juvenile diabetes mellitus. Clin Endocrinol 2:233-248

61. Warren S, Root HF (1925) The pathology of diabetes, with special reference to pancreatic regeneration. Am J Pathol 1:415-429

62. Pipeleers D, Ling Z (1992) Pancreatic beta cells in insulin-dependent diabetes. Diabetes Metab Rev 8:209-227

63. Campbell-Thompson ML, Atkinson MA, Butler AE, Chapman NM, Frisk G, Gianani R, Giepmans BN, von Herrath MG, Hyöty H, Kay TW, Korsgren O, Morgan NG, Powers AC, Pugliese A, Richardson SJ, Rowe PR, Tracy S, In't Veld PA (2013) The diagnosis of insulitis in human type 1 diabetes. Diabetologia 56:2541-2543

64. Dabelea D, Mayer-Davis EJ, Andrews JS, Dolan LM, Pihoker C, Hamman RF, Greenbaum C, Marcovina S, Fujimoto W, Linder B, Imperatore G, D'Agostino R (2012) Clinical evolution of beta cell function in youth with diabetes: the SEARCH for diabetes in youth study. Diabetologia 55:3359-3368

65. Greenbaum CJ, Beam CA, Boulware D, Gitelman SE, Gottlieb PA, Herold KC, Lachin JM, McGee P, Palmer JP, Pescovitz MD, KrauseSteinrauf H, Skyler JS, Sosenko JM (2012) Fall in C-peptide during first 2 years from diagnosis: evidence of at least two distinct phases from composite type 1 diabetes TrialNet data. Diabetes 61:2066-2073

66. Rahier J, Goebbels RM, Henquin JC (1983) Cellular composition of the human diabetic pancreas. Diabetologia 24:366-371

67. Stefan Y, Orci L, Malaisse-Lagae F, Perrelet A, Patel Y, Unger RH (1982) Quantitation of endocrine cell content in the pancreas of nondiabetic and diabetic humans. Diabetes 31:694-700

68. Löhr M, Klöppel G (1987) Residual insulin positivity and pancreatic atrophy in relation to duration of chronic type 1 (insulin-dependent) diabetes mellitus and microangiopathy. Diabetologia 30:757-762

69. Keenan HA, Sun JK, Levine J, Doria A, Aiello LP, Eisenbarth G, Bonner-Weir S, King GL (2010) Residual insulin production and pancreatic beta cell turnover after 50 years of diabetes: Joslin Medalist study. Diabetes 59:2846-2853

70. Meier JJ, Bhushan A, Butler AE, Rizza RA, Butler PC (2005) Sustained beta cell apoptosis in patients with long-standing type 1 diabetes: indirect evidence for islet regeneration. Diabetologia 48: 2221-2228

71. Anderson MS and Bluestone JA (2005) The NOD mouse: a model of immune dysregulation. Annu Rev Immunol 447-485

72. Leiter EH (1977) The NOD mouse: a model for insulin-dependent diabetes mellitus. In: Current protocols in immunology, unit 15.9. Wiley, New York

73. Leiter EH (1993) The NOD mouse: a model for analyzing the interplay between heredity and environment in development of autoimmune disease. ILAR news 35:4-14 
74. Driver JP, Serreze DV, Chen YG (2011) Mouse models for the study of autoimmune type 1 diabetes: a NOD to similarities and differences to human disease. Semin Immunopathol 33:67-87

75. Carrero JA, Calderon B, Towfic F, Artyomov MN, Unanue ER (2013) Defining the transcriptional and cellular landscape of type 1 diabetes in the NOD mouse. PLoS ONE 8:e59701

76. Janssen A, Homo-Delarche F, Hooijkaas H, Leenen PJ, Dardenne M, Drexhage HA (1994) Immunohistochemical characterization of monocytes-macrophages and dendritic cells involved in the initiation of the insulitis and beta cell destruction in NOD mice. Diabetes 43: $667-675$

77. Alanentalo T, Hörnblad A, Mayans S, Nilsson AK, Sharpe J, Larefalk A, Ahlgren U, Holmberg D (2010) Quantification and threedimensional imaging of the insulitis-induced destruction of beta cells in murine type 1 diabetes. Diabetes 59:1756-1764

78. Quah HS, Miranda-Hernandez S, Khoo A, Harding A, Fynch S, Elkerbout L, Brodnicki TC, Baxter AG, Kay TWH, Thomas HE, Graham KL (2013) Deficiency in type I interferon signaling prevents the early inteferon-gene signature in pancreatic islets but not type 1 diabetes in non-obese diabetic mice. Diabetes (in press)

79. Aloisi F, Pujol-Borrell R (2006) Lymphoid neogenesis in chronic inflammatory diseases. Nat Rev Immunol 6:205-215

80. Hjelmstrom P, Fjell J, Nakagawa T, Sacca R, Cuff CA, Ruddle NH (2000) Lymphoid tissue homing chemokines are expressed in chronic inflammation. Am J Pathol 156:1133-1138

81. Penaranda C, Tang Q, Ruddle NH, Bluestone JA (2010) Prevention of diabetes by FTY720-mediated stabilization of peri-islet tertiary lymphoid organs. Diabetes 50:1461-1468

82. Sreenan S, Pick AJ, Levisetti M, Baldwin AC, Pugh W, Polonsky KS (1999) Increased beta cell proliferation and reduced mass before diabetes onset in the nonobese diabetic mouse. Diabetes 48:989-996
83. Sherry NA, Kushner JA, Glandt M, Kitamura T, Brillantes $\mathrm{AB}$, Herold KC (2006) Effects of autoimmunity and immune therapy on beta cell turnover in type 1 diabetes. Diabetes 55: 3238-3244

84. Dirice E, Kahraman S, Jiang W, El Ouaamari A, De Jesus DF, Teo AKK, Hu J, Kawamori D, Gaglia JL, Mathis D, Kulkarni RN (2014) Soluble factors secreted by $\mathrm{T}$ cells promote beta cell proliferation. Diabetes 63:188-202

85. Fujita T, Yui R, Kusumoto Y, Serizawa Y, Makini S, Tochino Y (1982) Lymphocytic insulitis in a 'non-obese diabetic (NOD)' strain of mice: an immunohistochemical and electron microscope investigation. Biomed Res 3:429-443

86. In't Veld PA, De Munck N, van Belle K, Buelens N, Ling Z, Haentjens P, Gorus F, Pipeleers-Marichal M, Pipeleers D (2010) Beta cell replication is increased in donor organs from young patients after prolonged life support. Diabetes 59:17021708

87. Willcox A, Richardson SJ, Bone AJ, Foulis AK, Morgan NG (2010) Evidence of increased islet cell proliferation in patients with recentonset type 1 diabetes. Diabetologia 53:2020-2028

88. Skog O, Korsgren S, Melhus A, Korsgren O (2013) Revisiting the notion of type 1 diabetes being a T-cell mediated autoimmune disease. Curr Opin Endocrinol Diab Obes 20:118-123

89. Korsgren O, Molin Y, Salmela K, Lundgren T, Melhus A, Korsgren $O$ (2012) On the etiology of type 1 diabetes: a new animal model signifying a decisive role for bacteria eliciting an adverse innate immunity response. Am J Pathol 181:17351748

90. In't Veld P (2011) Insulitis in the human endocrine pancreas: does a viral infection lead to inflammation and beta cell replication? Diabetologia 54:2220-2222 